\title{
The mesozooplankton in the wadden sea of Sylt (North Sea)
}

\author{
W. HICKEL \\ Biologische Anstalt Helgoland (Zentrale); \\ Hamburg 50, Federal Republic of Germany
}

\begin{abstract}
KURZFASSUNG: Das Mesozooplankton im Sylter Wattenmeer (Nordsee). Untersuchungen der Anzahl und Biomasse der wichtigsten Zooplankter $(>150 \mu \mathrm{m})$ im Sylter Wattenmeer von März bis November zeigten, daß auch im Wattenmeer mit seinem hohen Anteil meroplanktischer Larven die holoplanktischen calanoiden Copepoden stets dominieren. Vier Copepodenarren bildeten im Mittel $85 \%$ der Zooplanktonbiomasse. Lediglich von Juni bis September waren andere Gruppen nennenswert vertreten, vor allem Polychaetenlarven (15\% der Biomasse von Juli bis September), harpacticide Copepoden und Appendicularien.
\end{abstract}

\section{INTRODUCTION}

The abundance and relative significance of the main mesozooplankton groups were examined in a semi-enclosed wadden sea area between the islands of Sylt and Röm and the mainland of Schleswig-Holstein (Germany) and Denmark (Fig. 1). The area is separated from the neighbouring wadden sea by the Römö dam in the North and the Hindenburg dam in the South. Hence water exchange takes place only through the narrow Lister Deep. The wadden sea is protected from the prevailing westerly winds and receives freshwater inflow mainly from one creek. Strong tidal currents up to 2-3 knots (Atlas der Gezeitenströme, 1968) in the tidal channels prevent vertical stratification. The wadden sea of Sylt ("Nordsylter Wattenmeer") covers $418 \mathrm{~km}^{2}$, of which $52 \%$ fall dry at mean spring low water (nautical map No. 108, German Hydrographical Institute). The mean tidal range is $1.7 \mathrm{~m}$.

Some geographical, hydrographical and ecological facts about the wadden sea of Sylt can be found in the papers of HagmeIER \& KäNDLER (1927), KäNDLER (1928), and KÜNNE (1952); the latter presents qualitative zooplankton data. The investigations of SMIDT (1951) on animal production of the neighbouring Danish Wadden Sea include some zooplankters. Quantitative zooplankton data of the wadden sea of Sylt have not been published so far.

\section{MATERIAL AND METHODS}

Zooplankton was investigated in 436 water samples, taken from March until November 1972, from a landing stage near the harbour of List (Sylt), which extends 
into the Lister Ley, one of the three main channels of the wadden sea (Fig. 1). The tidal current reaches the stage and ensures a water quality here similar to that in the midst of the channel. Usually twice a day, a 10-1 surface water sample was taken about $3 \mathrm{~h}$ after slack water during the time of maximal tidal current; this means that a mixture of the two main water masses was monitored: the North Frisian coastal water west of the islands and the inner wadden sea water.

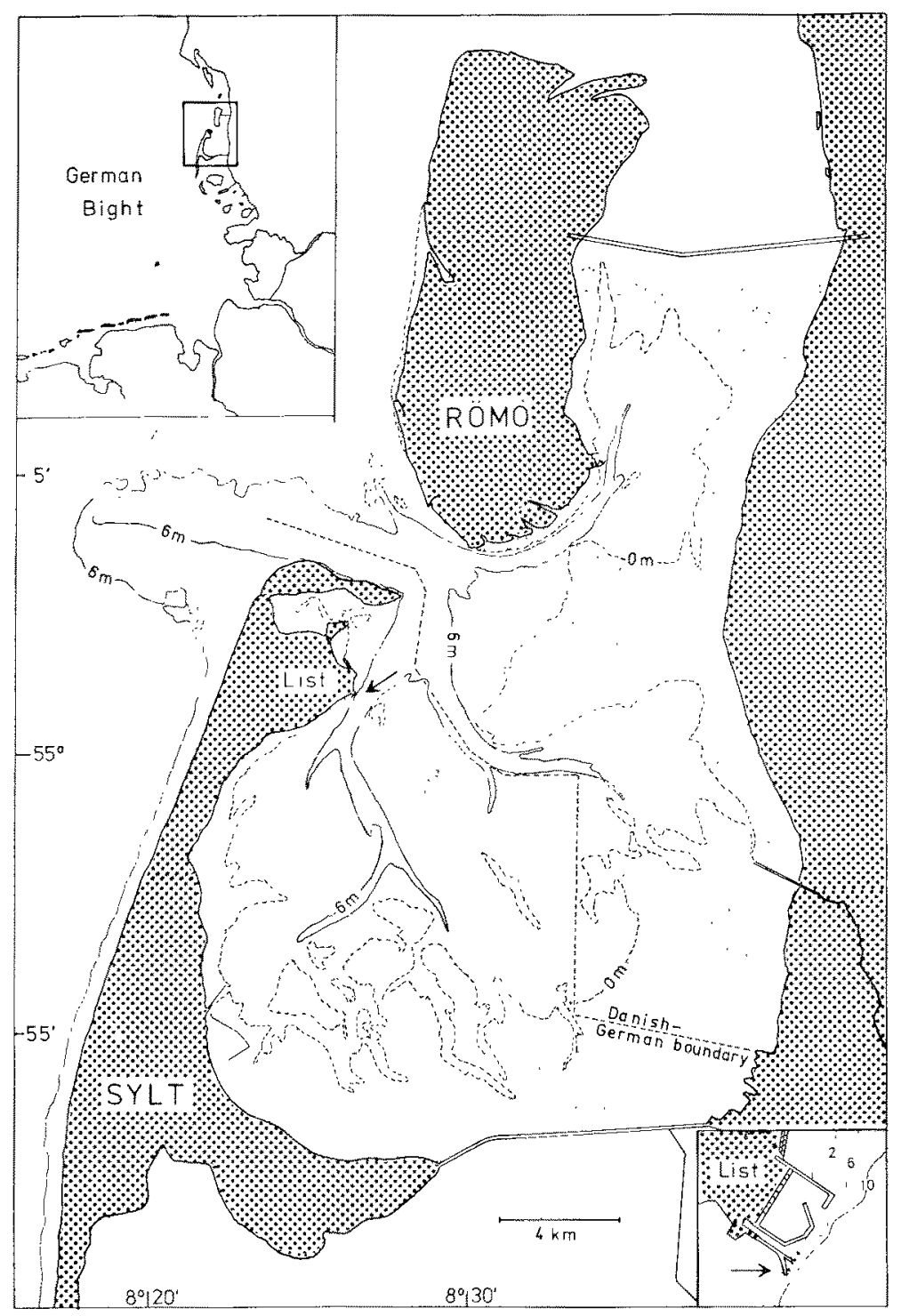

Fig. 1: Map of the wadden sea of Sylt. Depths refer to mean spring low tide. Mud flats are dotted. The arrows indicate the sampling location (List harbour) 
The 10-1 water sample was screened through a $150-\mu \mathrm{m}$ mesh sieve and the plankton preserved in formalin. Thus the microzooplankton, consisting mainly of protozoans and nauplii, was partly lost and not included in the count. The mesozooplankton, however, which usually dominates the zooplankton biomass, was quantitatively included. It was counted under the dissecting microscope using the whole sample. Only the four dominant adult copepods were determined to the species level. The counts were converted to zooplankton carbon as a measure of biomass. The zooplankton volumes according to LoHmanN (1908) were used (with some modifications), and converted to carbon, making the following assumptions: specific weight 1.0, organic dry weight $18 \%$ of wet weight (volume), and organic carbon $60 \%$ of zooplankton organic dry weight, resulting in a factor zooplankton volume $\times 0.11=$ zooplankton organic carbon. For the counted zooplankters the carbon data (in $\mu \mathrm{g} \mathrm{C}$ per individual) were used as follows: Acartia clausi, 1.54; Centropages hamatus, 2.75 ; Psendocalanus elongatus, 2.53; Temora longicornis, 2.86; copepodites, 0.30 ; harpacticoid copepods, 0.30 ; appendicularians, 0.50 ; and polychaete larvae, 1.20 . The conversion is more accurate in single copepod species than in the heterogeneous groups converted by a mean factor.

Water temperature and salinity were measured to an accuracy of $0.1^{\circ} \mathrm{C}$ and $0.01 \% \mathrm{~S}$, respectively. Meteorological data were obtained from the Meteorological Station at List. The water levels, measured near List, were taken from the "Deutsches Gewässerkundliches Jahrbuch".

\section{RESULTS}

The summer 1972 was very dry and warm as compared to the average summer of past decades. A continuous increase of salinity was observed from June until October, but not the usual salinity oscillations. Low wind velocity and no extreme tidal ranges were recorded during this period (Fig. 2). Additional hydrographical measurements in August revealed that the salinity of the wadden sea water was much the same as that of the open coastal water.

During the calm-weather period, great fluctuations in zooplankton stocks were observed (Figs. 3 and 4). Three of the four distinct maxima of calanoid copepods, which occurred at time intervals of 1 or 2 months, were found in this period and are not explained by changes in hydrographical conditions. Whereas calanoid copepods were frequent also in April and May during unstable weather conditions, polychaete larvae, harpacticoid copepods and appendicularians were found in great numbers only from June until September at water temperatures exceeding $13^{\circ} \mathrm{C}$. At the end of October, the copepod stock declined rapidly during a period of strong winds and high water levels, obviously followed by a different water mass, as indicated by the decline of salinity and temperature in November (Fig. 2).

Numerically, calanoid copepods form by far the most important zooplankton group (Fig. 3) and constitute the main biomass (Figs. 4 and 5). Mean copepod concontrations of 2 to 9 individuals per litre were found, representing an estimated biomass of about 4 to $17 \mu \mathrm{g}$ carbon $\mathrm{l}^{-1}$. Only four copepod species were of quantitative importance: Acartia clausi, Centropages hamatus, Temora longicornis and Pseudocalanus 
Mesozooplankton in the wadden sea of Sylt

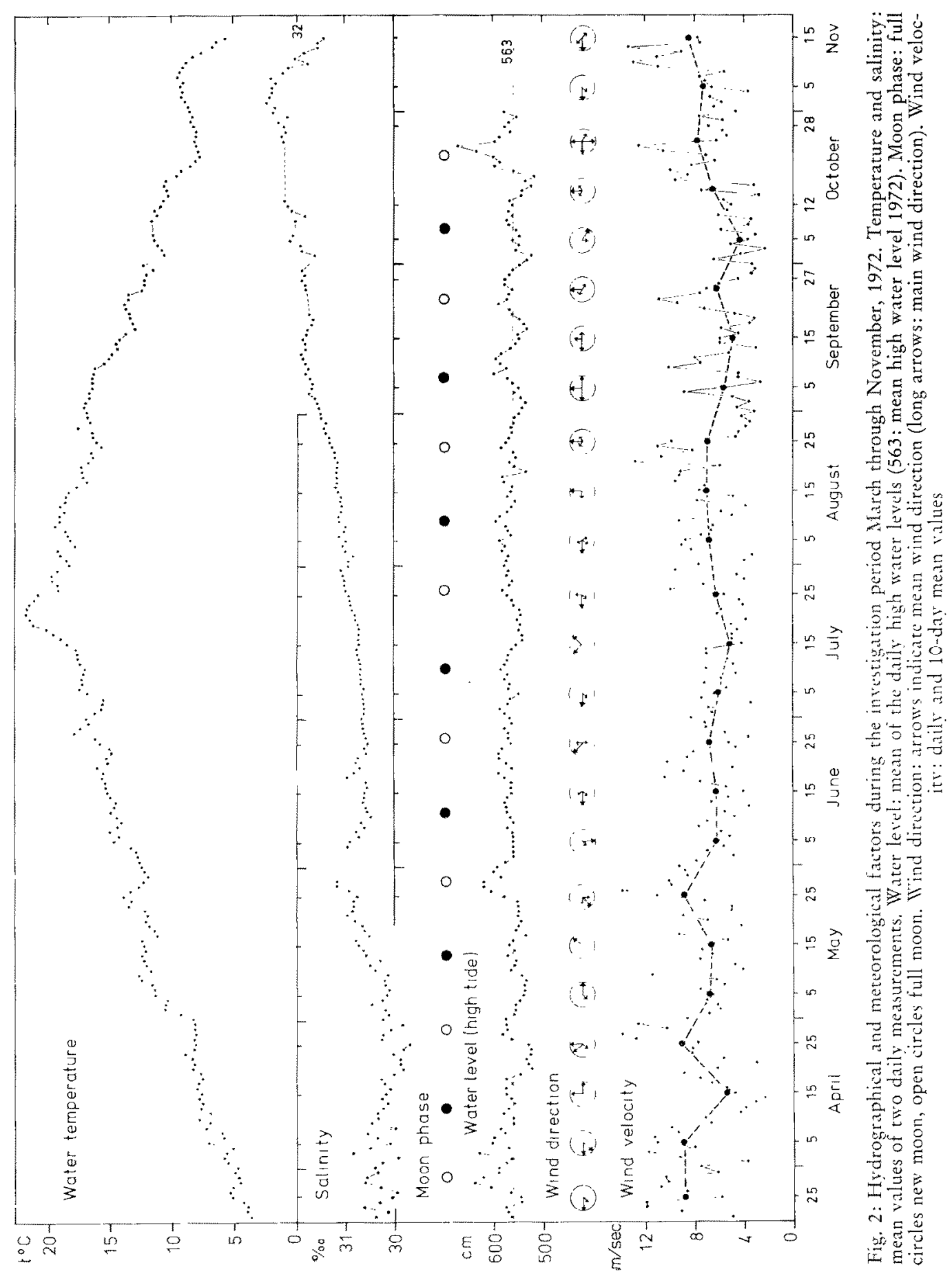


W. HICKEL
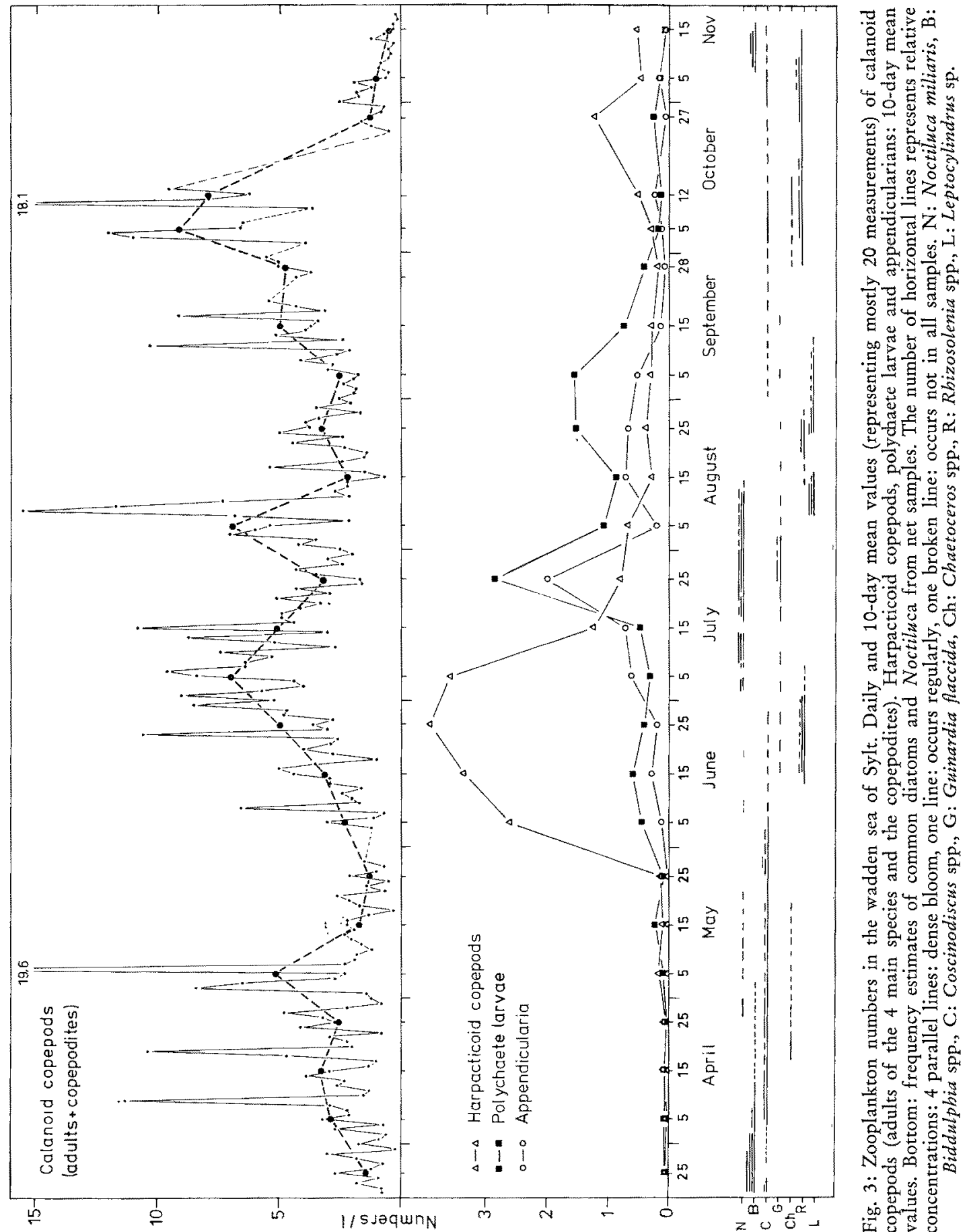
Mesozooplankton in the wadden sea of Sylt

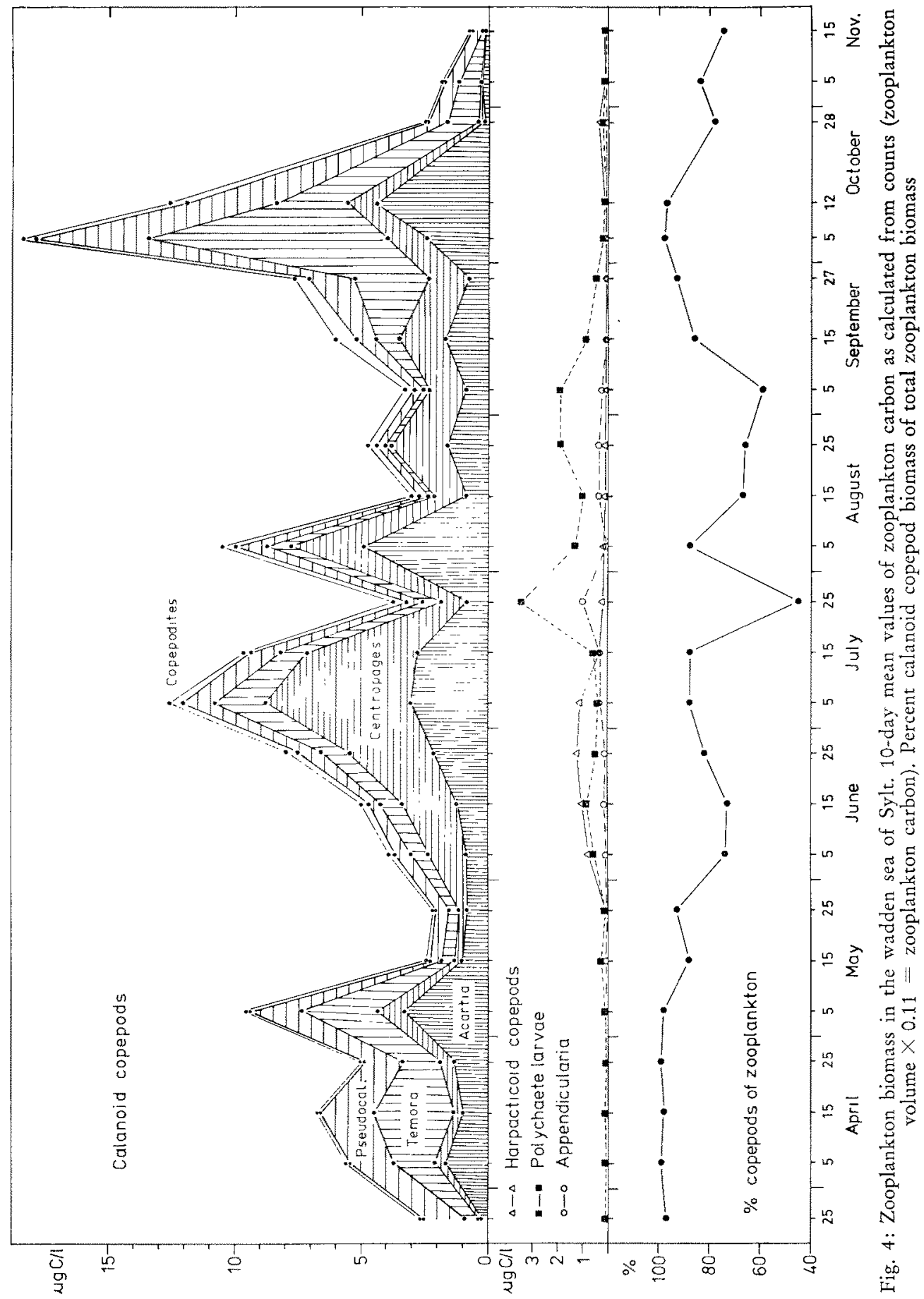


elongatus. On an average, these species form $85 \%$ of the zooplankton biomass $(7.4 \mu \mathrm{g}$ $\mathrm{C}^{-1}$. A frequency estimate of net phytoplankton is included in Figure 3. Larger phytoplankton cells or colonies, retained to a major extent by the $150-\mu \mathrm{m}$ mesh sicve,

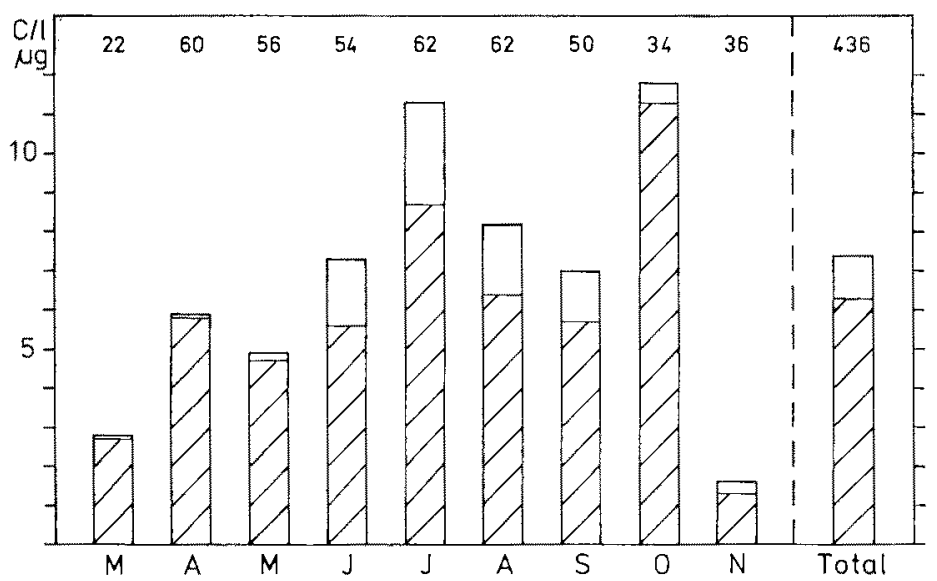

Fig. 5: Monthly mean values of zooplankton and calanoid copepod (hatched) biomass as carbon. Right column: mean of all values. Figures over the columns: number of samples

were estimated as frequency classes, symbolized by the number of horizontal lines in Figure 3. Of course, this excluded the smaller or non colony-forming algae - among them the more valuable food organisms.

\section{DISCUSSION}

The measurements were made in the transition zone between the coastal water and the inner wadden sea water, which both sweep past the sampling station off List in the course of the tidal cycle. The surface water samples investigated here were regarded to be representative for the water mass of the wadden sea channel because the sampling was done in a highly turbulent water with no vertical salinity gradient during maximum current. No correlation between copepod concentrations and hydrographical parameters could be found: salinity was not useful as an indicator for different water masses throughout the summer and autumn; the mean daily high water levels - as a measure of the amount of coastal water entering the wadden sea by combined force of tide and wind - were not correlated with the mean daily copepod concentrations. To interpret the copepod peaks as a succession of generations, however, can only be speculative because of the short retention time of the water in the outer wadden sea channels as compared to copepod generation time (about 1 to 2 months).

Copepods are the most important marine zooplankton group, at least in terms of biomass. This is confirmed here also for the wadden sea plankton, in spite of its exceptionally high proportion of meroplanktonic larvae. Even when polychaete larvae 
attain maximum abundance (25 July), the copepods still make up about $50 \%$ of the zooplankton biomass. During the period from July to September, the polychaete larvae constitute an average of $15 \%$ of the biomass. The four dominating copepod species are the same as found by KüNNE (1952) in the wadden sea of Sylt and by LücKE (1910) and by KRAEFFT (1910) in the coastal zooplankton of the German Bight. However, these authors found the harpacticoid copepod Oithona similis to be often frequent as well. These five species made up $99 \%$ of the total number of copepods present (KRAEFFT 1910).

Published copepod concentrations in wadden sea and coastal waters were based on net samples and seem to be about one order of magnitude lower than quantitative counts from water samples reported here; the same holds for tropical waters (HickeL 1974). Five to 20 copepods per 101 are generally found in neritic waters (RAYMONT 1963). SMIDT (1951) obtained 1 to 10 copepods per 101 (monthly means from March until. November) from net samples at a comparable site in the Danish wadden sea off Esbjerg, with an average of 3 copepods per 101 . From the data reported here, a mean concentration of 37 copepods 101 is found for the same seasons.

The non-selective zooplankton feeders take advantage of the great amount of particulate organic carbon present the whole year in the wadden sea in form of detritus. Concentrations of 600 to $1500 \mu \mathrm{g}$ carbon $l^{-1}$ have been measured in August 1972 off List (zooplankton carbon: $8 \mu \mathrm{g}^{-1}$ ). The relatively high zooplankton concentrations, represent an important food source for fish and fish larvae which are known to invade the wadden sea during the summer season. In addition to young flat fish, feeding mostly on benthic animals, young Cupea barengus and C. sprattus are found in summer and are large-scale zooplankton consumers. SMIDT (1951) found 15 small herring of $4-5 \mathrm{~cm}$ length which had their stomachs filled with pelagic copepods (40-50 per stomach). Also Balanus larvae and larger bottom-animal larvae were eaten.

\section{SUMMARY}

1. Abundance and biomass of the quantitatively most important zooplankters $(>150 \mu \mathrm{m})$ were investigated in the wadden sea between the island of Sylt and the North Frisian Coast from March until November, 1972. Zooplankton screened from 101 surface water samples twice daily was counted under the microscope and calculated zooplankton carbon was taken as biomass measure.

2. In spite of the larse number of meroplanktonic larvae present, calanoid copepods (Acartia clausi, Centropages hamatus, Temora longicornis and Pseudocalanus elongatus) dominated with an average of $85 \%$ (including copepodites) of the zooplankton biomass $\left(7.4 \mu \mathrm{g} \mathrm{C}^{-1}\right)$. The great fluctuations in copepod stocks were not related to hydrographical changes during summer and autumn.

3. The copepod concentrations recorded were about one order of magnitude higher than those published from neighbouring wadden sea and coastal waters using plankton nets.

4. Only from June to September, other zooplankton groups were of quantitative significance, mainly the polychaete larvae, which made up $15 \%$ of the zooplankton 
biomass from July to September. A mass occurrence of harpacticoid copepods was restricted to the beginning of June until the beginning of July. Appendicularians were abundant from July to September.

Acknowledgements. I wish to thank Dr. G. LUTHER for making the zooplankton samples available to me. The aid of Mr. A. WINTER in counting the zooplankton and the careful assistance of Miss A. REINERs are gratefully acknowledged.

\section{LITERATURE CITED}

Atras der Gezeitenströme für die Nordsee, den Kanal und die Irische See, 1968. Seehydrogr. Dienst der DDR, Rostock, 58 pp.

DeUtsches gewässerkundliches Jahrbuch, 1973. Landesamt f. Wasserhaushalt und Küsten Schleswig-Holstein, Kiel, Abflußjahr 1972, 1-158.

HAGMEler, A. \& KäNDLER, 1927. Neue Untersuchungen im Nordfriesischen Wattenmeer und auf den fiskalischen Austernbänken. Wiss. Meeresunters. (Helgoland) 16 (2), 1-90.

HICKEL, W., 1974. Seston composition of the bottom waters of Great Lameshur Bay, St. John, U. S. Virgin Islands. Mar. Biol. 24, 125-130.

KäNDLER, R., 1928. Untersuchungen über die Biologie der Auster. Nr. 3. Verbreitung und Wachstum der Austernbrut im Wattenmeer. Planktonuntersuchungen im Sommer 1926 und 1927 nach der Aussetzung holländischer Saataustern. Wiss. Meeresunters. (Helgoland) 17 (1), 1-35.

KraefFt, F., 1910. Uber das Plankton in Ost- und Nordsee und in den Verbindungsgebieten, mit besonderer Berücksichtigung der Copepoden. Wiss. Meeresunters. (Kiel) 11, 29-99.

KüNNE, C., 1952. Untersuchungen über das Großplankton in der Deutschen Bucht und im Nordsylter Wattenmeer. Helgoländer wiss. Meeresunters. 4, 1-54.

LoHmanN, H., 1908. Untersuchungen zur Feststellung des vollständigen Gehaltes des Meeres an Plankton. Wiss. Meeresunters. (Kiel) 10, 129-370.

Lǘcк, F., 1912. Quantitative Untersuchungen an dem Plankton bei dem Feuerschiff „Borkumriff" im Jahre 1910. Wiss. Meeresunters. (Kiel) 14, 101-128.

Raymont, J. E. G., 1963. Plankton and productivity in the oceans. Pergamon Press, Oxford, $660 \mathrm{pp}$.

Smor, E. L. B., 1951. Animal production in the Danish Waddensea. Meddr. Kommn. Danm. Fisk.- og Havunders. (Fiskeri) 11 (6), 1-151.

Author's address: Dr. W. Hickel

Biologische Anstalt Helgoland (Zentrale)

D-2 Hamburg 50

Palmaille 9

Federal Republic of Germany 